\title{
Zambian Constitutional Normativity on Religion
}

\author{
Antonios Maniatis \\ University of Patras, GREECE \\ Department of Administrative Science and Technology
}

Received: 1 March 2020 - Accepted: 17 May 2020 - Published Online: 18 June 2020

\begin{abstract}
The Republic of Zambia from scratch has consecrated the freedom of religion as a constitutional right. From 1996 and onwards, it has gradually consecrated Christianism in the 1991 Constitution. In a similar way, it attempts to amend its Constitution as far as inter alia religious matters are concerned. This amendment implicates the replacement of the word "multireligious" by the word' "Christian", as for Zambian nation and State. In a similar way, the "morality and ethics" as one of the national values and principles are proposed to be transformed into "Christian morality and ethics". These proposed changes are in opposition to the constitutional principle of pluralism (multi-culturalism) whilst both democracy and freedom of religion are limited by the Constitution, allowing no political parties founded on religious basis.
\end{abstract}

Keywords: religion, Zambia, human rights, flexible/rigid constitutions, national values and principles, constitutional normativity, multi-religious state.

\section{Introduction: Zambia Christianizing its Constitution}

The Republic of Zambia constitutes an important case of state in constitutional terms, which has gained the world interest from scratch. Indeed, in its brief Constitutional History, it started its post-independence period with a Constitution, adopted in 1964, which established a (presidential, non-parliamentary) Republic as a form of state. This development was not the common practice as for the colonies coming from the UK rule. Till then, with the unique exception of the Republic of Cyprus, which however is characterized as a sui generis case, all colonies of this colonial power had begun their independent life with the Queen as the head of State. More precisely, those territories of the UK had hitherto gone into independence with a monarchical form of government, and with the Queen represented by a Governor-General. This novelty of Zambia was not presented by the UK as an indication that the people in Northern Rhodesia had any antipathy to the connection with the Crown. Rather it should be seen as a realistic acceptance, right at the outset, of what many African countries had found, after only a brief period of independence, the medium best adapted to their political aspirations. The UK granted to Zambia a Constitution being related to the Zambia - Barotseland agreement of the same year, which was terminated in 1969 at the expense of Barotseland (Caplan, 1970). So, some specific privileges of the community of Barotseland should be respected, in a unitarian, democratic state, the Republic of Zambia. This institutionalization of an ad hoc regime was by nature problematic, as in a way it encouraged the centrifugal tendencies of a particular community, let alone a former "protectorate within the protectorate" of Northern Rhodesia, in a new state having no federal structure (Maniatis, 2019).

(C) Authors. Terms and conditions of Creative Commons Attribution 4.0 International (CC BY 4.0) apply. Correspondence: Antonios Maniatis, Academic Fellow of the University of Patras, Koutifari Street 8, Kalamata 24134, GREECE. E-mail: maniatis@dikaio.gr. 
Christianism ...

- ... was not consecrated in the initial Constitutions of Zambia

- ... was introduced in the 1991 democratic Constitution in 1996.

- ... has constituted to date the identity of the Republic.

If Zambia has had since the beginning of its existence some relatively original features in its constitutional profile and also important problems, such as inter alia neo-patrimonialism (Soest, 2009), it would be interesting to examine its actual process of amendment of its Constitution, as far as religious matters are concerned. A research on this topic is by nature oriented to examine in a global way religious normativity, in the constitutional order of this Commonwealth member.

The most recent constitutional developments on religion consist in:

- The 2016 clause on the acknowledgment of the supremacy of God Almighty.

- The 2016 clause on the multi-religious character of the Republic of Zambia.

- The 2019 amendment process to delete the clause on multi-religious character.

- The 2019 amendment process to institutionalize Christian morality and ethics.

First of all, the current paper focuses on a classic human right, consisting in the freedom of religion that is consecrated in the Bill of Rights.

Afterwards, it examines the contradictory normativity on religion, in Zambian Constitution beyond the Bill of Rights.

Then, it highlights the convergence of constitutional regulations on religion and language, as components of Zambian nation.

Besides, it deals with modernization being influenced by neo-colonialism.

Furthermore, it localizes some cases of forced dynamic of the Republic of Zambia towards citizens.

Finally, it ends up to some critical remarks on the institutionalization of Christianism in the Constitution, in comparison with the phenomenon of constitutionalism.

\section{The freedom of religion in the Bill of Rights}

The freedom of religion has been consecrated in Part III of the 1991 Constitution of Zambia. This part entitled "Protection of the fundamental rights and freedoms of the individual", constitutes an extended and detailed Bill of Rights, which is similar to the initial one, included in the 1964 Constitution, and has remained unchanged, to date. The two amendments of the current Constitution, namely of 1996 and 2016, did not change the content of the Bill.

The freedom of religion is incorporated in article 19 under the title "Protection of freedom of conscience" whilst article 14 (3)c refers to the labor that person is required by law to perform in place of military service, with no explicit use of the term "religion".

In virtue of paragraph (1) of article 19, "Except with his own consent, a person shall not be hindered in the enjoyment of his freedom of conscience, and for the purposes of this Article the said freedom includes freedom of thought and religion, freedom to change his religion or belief, and freedom, either alone or in community with others, and both in public and in private, to manifest and propagate his religion or belief in worship, teaching, practice and observance." 
Paragraph (2) consecrates the right of a person to abstain from religious instruction, ceremony and observance related to a religion other than his own.

Paragraph (3) previews the right of religious community or denomination to provide instruction for its persons as well as to establish and maintain instructions to provide social services for such persons. The second right of these guarantees is the unique substantial change between the 1991 Constitution and the 1964 one, as for the right to religion.

Paragraph (4) protects a person from taking oath being contrary to his religion or belief whilst paragraph (5) tolerates any reasonable law, required in the interests of defense, public safety, public order, public morality or public health or for the protection of the rights and freedoms of other persons. It is notable that there is a constitutional tradition of limitations on the recognition of civil rights. Already in the 1964 Constitution, the consecrated rights were subject to various detailed limitations.

\section{Contradictory normativity on religion}

There is a gradual tendency, during the Third Republic, namely from 1991 onwards, to recognize the Christian identity of the people of Zambia and particularly of the State.

Against the recommendation of the Mwanakatwe amendment process Commission and over the objections of many of the churches, the government inserted in the Preamble of the 1996 version of the Constitution a provision to declare "the Republic a Christian nation while upholding the right of every person to enjoy that person's freedom of conscience or religion". It rejected the Mwanakatwe report's recommendation that there should be separation of Church and State (Ndulo \& Kent, 1996). This institutional connection between Church and State is opposite to other constitutional provisions of many African constitutions, which explicitly prohibit the amendment of this separation. For instance, Article 236 of the Constitution of Angola enumerates a list of prohibited topics, such as "The secular nature of the state and the principle of separation of church and state" (Metou, 2019).

However, Mediterranean states of Africa have consecrated explicitly their Islamic character, in their Constitutions, which are not flexible. For instance, article 178 of the Algerian Constitution bans any constitutional revision inter alia on Islam, as the religion of the State. There are similar dispositions, prohibiting constitutional amendments of some topics, in almost all African constitutions (Metou, 2019). It is to underline that there is a constant tendency for African constitutions to be rigid, establishing much or less important conditions for their amendment and excluding any amendment in some subjects. In this context, religion not only is present but also the principle of separation of church and state in many Constitutions is explicitly consecrated and endowed with the "privilege" of ban on amendment.

This is not valid for Zambian Constitutions, which have not been very rigid and therefore are quite similar to the republican Constitution of Italy, which was put into force in 1948 and is classified among the less rigid constitutions (Papagrigoriou, 1995). For instance, with the exception of parts of the Constitution relating to fundamental rights, the 1964 Constitution just required a two-thirds majority of the members of Parliament.

The 2016 version of the Constitution did not interrupt the tradition of too detailed texts, coming from the colonial era (Ndulo \& Kent, 1996). It makes the step forward with the delicate question of religious belief, as at the beginning of the Preamble it includes a new disposition, according to which the people of Zambia acknowledge the supremacy of God Almighty.

This stereotype expression of Christianity is completed by the afore-mentioned clause on the Christian character of the nation of the Republic, as this identity is counterbalanced by the 
recognition of the freedom of religion. The formulation has been enriched, given that the Republic upholds a person's freedom not only of conscience or religion but also of belief.

Anyway, the identity of the Republic as a Christian nation is contradictory to the new mention of the Preamble, consisting in the multi-religious character of the nation. The lack of cohesion and particularly the defect of conceptual repetitions are obvious in the main text, in which the Republic is characterized as a multi-religious state. Paragraph (3) of article 4 consecrates, though not explicitly, the principle of pluralism, as follows: "The Republic is a unitary, indivisible, multi-ethnic, multi-racial, multi-religious, multi-cultural and multi-party democratic state".

Besides, it is to put the stress on the fact that potential and existent political parties are oppressed, as long as the Constitution prohibits any party ideologically identified as a religious one. More precisely, article 60 is demanding as for the operation of political parties, to such a pitch that imposes the principle of internal democracy. This rather maximalist approach is also obvious in another disposition of this article, which prohibits a political party to "be founded on a religious, linguistic, racial, ethnic, tribal, gender, sectorial or provincial basis or engage in propaganda based on any of these factors".

This regulation is unfamiliar to the Western model, which is compatible with religionbased parties. The mainstreaming example consists in Christian democracy, which was the most important party in the period of First Italian Republic and also in political terms marked that period so much that the doctrine characterizes that period as a one-party governance. Instead of proposing the repeal of the aforementioned antidemocratic regulation, the Constitution of Zambia (amendment) Bill, adopted in 2019, includes another proposal relevant to political parties.

The scope of this Bill is to amend the Constitution so as to revise the Preamble in order to reaffirm the Christian character of Zambia. It is about the 2016 novelty, already mentioned, on the multi-religious character of Zambian nation. As the term "multi-religious" is deleted and substituted by the word "Christian", this change could not be isolated, it is completed by the same substitution in the aforementioned paragraph (3) of article 4.

In addition to this labeling, article 8 of the Constitution is amended by the deletion of paragraph (a) and the substitution therefor of the following paragraph: "(a) Christian morality and ethics;" against the current mention of morality and ethics, among the national values and principles. It is about values and principles applying to the interpretation of the Constitution, enactment and interpretation of the law as well as development and implementation of State policy. So, there is an extension of the consecration of Christianism, from the nation (society) to the State, which is endowed with a national identity.

\section{Convergence of regulations on religion and language as components of a nation}

It is remarkable that classical components of the concept of nation, such as religion and language, have been an object of (separate) regulation in Zambian Constitution. This proves that there is a great concern of the constituent power to control social developments and foster a concrete identity of both the constitutional state and the citizens' society.

The convergence of regulations on religion and language seems to exemplify the general principle of pluralism, but religion cannot be fully equalized to language, as far as State policy is concerned. Article 258 of the Constitution, being specific on languages, ensures the dominance of the English language, which is consecrated as the (unique) official language of Zambia. However, the privilege of this language, related to British colonialism, has acquired significant counterbalances. First of all, paragraph (2) of this article previews that a "language, other than English, may be used as a medium of instruction in educational institutions or for 
legislative, administrative or judicial purposes, as prescribed". Furthermore, paragraph (3) guarantees the diversity of the languages of the people of Zambia as a State duty.

The diversity of languages in Zambian society has been established as a "special obligation" of the State, in constitutional terms, whilst the State has to pay respect for religions and cannot interfere in the competition among religions, let alone among denominations within the same religion. It results that the freedom of religion remains a typical civil right, corresponding to a policy of tolerance, on behalf of political power. In this context, the multi-religious character of a state is a rather disorienting concept.

\section{Modernization influenced by neo-colonialism}

Colonialism formally collapsed in 1960 s in Africa, but it had already produced some positive effects as for human rights of the indigenous population, like the prohibition of slavery child marriages and forced marriages (Sakala, 2013). If it was replaced by self-governance, it essentially remained, perhaps with the unique exception of the phase of authoritarian regimes, such as the socialist, one-party ones in various countries, like Tanzania and Zambia. The current era of African countries is not merely the post-cold war period of democratic Republic model. It is also more or less marked by the phenomenon of neo-colonialism, which therefore coexists with the typical, for this era, development of constitutionalism, being explicitly consecrated in aforementioned article 8 of Zambian Constitution, as one of the national values and principles. It is about the phase of neo-constitutionalism in various regions, such as Africa and Latin America. The neocolonial politics have continued to reframe religious beliefs and practices into ideological state apparatus to manipulate and control religious citizens to think and approach politics in ways that are beneficial to the interests of those in power (Kaunda, 2018).

The introduction of constitutional normativity, such as the existent or the proposed one in Zambia, is not simply useful for political targets of politicians and political parties in the internal life of the country, namely to gain votes from devout Christian voters. It may also be useful for the diplomatic mobility of the State, mainly towards its former colonialists and other powerful countries, whose overwhelming majority of the people are Christians. This convergence, being anyway attributed to the historical phenomenon of penetration of missionaries, companies and the State itself of the colonial power involved, is a quite impressive image towards powerful states and international organizations. It results essentially a kind of religious diplomacy, let alone with some of the most powerful factors of the international context.

In this chain of ideas, this image-making process through the adoption and interpretation of new rules in the Constitution is not merely something that could be proved to be useful for the diplomatic position of Zambia, being particularly interested for good international relations and investments made by foreign factors in the current era of globalization. It has also to do with a psychological need of feeling something particular, if not unique, in the wider geographical area; the prestige of a sovereign country being created through the fusion of two protectorates of the UK, such as Northern Rhodesia and Barotseland, is enhanced as long as a Western-type cultural element, like Christianism, is explicitly introduced in the Preamble of the Constitution. This profile is promoted further as long as this development takes place in the main body of this text.

In other words, the explicit attachment of mainstreaming Christian belief to the State is not uniquely open for interpretations upon Constitutional law but also interpretable from theological point of view. First of all, as already signalized, there are African constitutions consecrating Islam as the state religion, let alone protecting it from any amendment attempt. So, Zambian nation demonstrates its "religiously correct" orientation, against non-Christian 
countries. Similar remarks are valid for the comparison of Zambia with other African states, which have consecrated their secular nature.

Besides, it would not be accurate to present Zambia as the unique country in the world that openly has consecrated its religious identity in the Constitution. For instance, the Greek nation during its Revolution against the Ottoman Empire founded a Ministry on Education and Religions. Article 3 of the current Greek Constitution keeps establishing the relation between Hellenic Republic and religion. First of all, it begins with the preliminary phrase "In the name of the Holy and Consubstantial and Indivisible Trinity". To this phrase, having an autonomous position as there is no Preamble, is comparable the aforementioned clause of the Preamble of Zambian Constitution, relevant to the supremacy of God Almighty. Furthermore, paragraph 1 of article 3 of Greek Constitution previews that "The prevailing religion in Greece is that of the Eastern Orthodox Church of Christ".

As far as Zambian nation is concerned, it would not be "politically correct" to institutionalize the prevailing position of one Christian denomination against the rest ones, namely following the Greek case. The declaration on Christian nation implies the unity of Christianity, but Zambia is far away from Greece, whose overwhelming majority is Orthodox, let alone the fact that Greek Orthodox Church had a significant role in Greek Revolution. Indeed, Zambia is marked by a significant division within Christianism and, as a result, the declaration rather tends to obscure religious diversity (Kaunda, 2018). It is also remarkable that the 2019 amendment proposals on religion are clearly supported by Pentecostal-Charismatic Church (Lumina, 2019). In a similar way, the majority of stakeholders that made submissions on the amendment Bill overwhelmingly supported the retention of the Christian nation clause in the preamble by deletion of the term "multi-religious" (IDEA, 2019). However, this proposed change has been rejected by Roman Catholic one, which has the largest number of believers in Zambia (Lumina, 2019). Besides, it is notable that Catholic Church worldwide has adopted the "Social Doctrine of the Church", which, designed to guide the behavior of private individuals, has been transformed into a systematic synthesis in 2004 (Maniatis, 2017). In the framework of this "codification" the Vatican includes the major principles of its social theory. It is about a tetraptych consisting in human dignity, common good, subsidiarity and solidarity.

\section{A forced dynamic of the State towards citizens}

The State in the territory which nowadays is Zambia has made use of institutionalized force or tends to make such a use towards the people, undermining more or less crucial human rights.

This oppressive approach, being in the margin of legality, if not clearly illegal, is exemplified by the following cases:

- Forced labor in the colonial era, as a substitute of the already abolished slavery;

- Quasi enforced participation to constitutional referendums, through the consecration of a turn-out quorum having led the 2016 constitutional referendum to failure;

- Forced participation of citizens invited in the National Dialogue Forum upon the Bill No. 6 of 2019, for the preparation inter alia of the new proposal for constitutional amendment.

Furthermore, another case could be added, this time relevant not to society itself but to citizens being a part of the powerful apparatus of the State. It is about the constitutional proposal to characterize the morality and ethics as Christian ones. If this tool is established, the way of Christianizing not only the internal structure and operation of the State but also the lifestyle of private individuals is open. This development would be ensured through the obligation of the 
State staff, included the civil and military parts of Public Administration, to make direct and explicit use of Christian rules, which to date have not constituted an official source of law. As this obligation would be universal within the structure of the Republic, it would result in forced application, if not also promotion, of Christian rules by public servants. In other words, members of Parliament, the staff of Public Administration as well as the judiciary would be thoroughly subject to Christian morality just due to their profession, even though they do not share Christian belief.

In other words, Christianism is essentially imposed as a public service to all members of State power.

\section{Conclusion: Christianism like constitutionalism}

The current study ends up to the following final remarks:

\section{(a) Ambivalent character of the constitutional amendment process}

Constitutions of Zambia have been presented as flexible documents, as for the possibility to amend them. In reality, their character is ambivalent on the matter, as they may be amended by Parliament, but with the augmented majority of two-thirds, not to speak about dispositions on fundamental rights (Part III of the Constitution) and on the amendment procedure itself (Article 79), for which even a constitutional referendum is required. It is notable that due to this normativity, in combination with the aforementioned turn-out quorum for the referendum (which is not directly required by the Constitution itself), the Bill of Rights constitutes the unique Part of the 1991 Constitution which has been intact, from 1991 and on, in spite of various amendment processes. The amendment of this Part has been associated to the political demand for a people-driven constitution, a phenomenon that is not well understood and sometimes is misleading, as it is difficult to know which is a people-driven or not people-driven Constitution (Chungu).

Besides, given that this Constitution has repeated, as a general rule, the content of the 1964 one, in the delicate matter of protection of fundamental rights, the Bill of Rights is quite old, if not in some points rather anachronistic. For instance, the freedom of religion is one of the most important classical civil rights in comparative law, so it would deserve an emphatical consecration whilst it is not mentioned in a separate way against the freedom of conscience. However, in some other points it is modern, such as the protection from taking oath contrary to the religion or belief of the person involved. Anyway, the constitutional tradition of Zambia consists in absolutely flexible Constitutions, as for the possibility to amend any part of the Constitution, the dispositions on fundamental rights and the constitutional amendment process included. This approach, already existent in the 1964 Constitution, did not protect the Republic of Zambia from the above-mentioned authoritarian governance. It seems quite paradoxical that the Zambian people put an end to their authoritarian, one-party regime, but adopted the initial provision, of the 1964 Constitution, on the amendment process.

In the post-cold war period of Zambian constitutional history, this flexible nature of the 1991 Constitution, which has survived to date, makes the democratic Republic of Zambia a very rare minority among African states, whose overwhelming majority is endowed with Constitutions explicitly prohibiting any amendment of some concrete topics, well exemplified by religion. This flexibility seems to be rare not only in the African context but also worldwide as well as problematic. Furthermore, it is notable that many African states (whose overwhelming majority of citizens are Christian or Muslim) have consecrated the separation of state and church whilst Zambian Constitution has been amended towards the opposite ideological direction, consisting in the recognition of the Christian identity. 


\section{(b) An ambivalent proposal for amendment on religion}

As already described, there is a gradual tendency, during the Third Republic, to recognize the Christian identity of the people of Zambia and particularly of the State. It is not about the recognition of empirical data, as the fact that the vast majority of the people are Christians, it is a matter of national identity for citizens, whose ancestors were not Christians but related to the indigenous tradition of animism. In this context, the 2019 proposals on religion are rather ambivalent, having caused mixed feelings, if not divergent views to Christian population. It is not clear which is the constitutional advantage of these changes, with the unique exception of the fact that the current version of the Constitution has an obviously contradictory content, with the coexistence of clauses on Christian nation and multi-religious character of the Republic. Perhaps, the multi-religious nature of the State seems anachronistic, due to the fact that the vast majority of people are Christians.

Constitutional principles and religious dogmas have historically served as ethical elements for unification of communities and societies (Marinho, 2014). Christianism has followed the way of Constitutionalism in Zambian Constitutional History (Maniatis, 2019). This religion, being typical of the Western world, has been incorporated initially in the culture of the people of Zambia, displacing a variety of religious and other similar traditional references of the indigenous people. On the one hand, it became a very powerful factor of convergence of Zambian nation but, on the other hand, it is marked by important diversity due to the coexistence of various Churches, such as mainly the Roman Catholic and Protestant denominations.

Christianism gained territory in the Constitution itself, in which constitutionalism has been so appreciated that it is explicitly consecrated among the national values and principles. In other words, irrespective of the issue of service of important political considerations in the internal political life of the country, the gradual penetration of Christianism in various points of the Constitution results from a sociocultural process of adoption of Western values, particularly of those of the colonial power involved. This "Europeanization" is interpreted by various political and ecclesiastical factors as a kind of significant progress, which makes Zambian nation (almost) unique in the international context (Kaunda, 2018) whilst a strong minority in the United Kingdom declares that it does not profess any religion.

Anyway, it is notable that Zambia has been a country with some particular features, which make it almost unique in comparative public law (Maniatis, 2019). If the most known feature on the matter has to do with the denial of any transitory form of state, being in connection with the UK crown, another feature has been highlighted in the framework of the current research. It consists in flexibility of Zambian constitutional texts, let alone their absolutely flexible character as for the question of amendable dispositions, in opposition to other Constitutions, particularly in Africa (Maniatis, 2019).

The penetration of Christianity into various points of the Constitution has proved to be gradual, it remains to be progressive, if Christianity finally is further established, with the pending amendment of the Constitution. Anyway, the clause on multi-cultural character of Zambian State, exemplifying the current African trend of multi-culturalism (Mwaebeme, 2019) and glocalization (Maniatis, 2019) in the framework of neo-constitutionalism that is not exempted from criticism (Senou, 2019), remains intact. 


\section{Acknowledgements}

This research did not receive any specific grant from funding agencies in the public commercial, or not-for-profit sectors.

The author declares no competing interests.

\section{References}

Caplan, G. (1970). The elites of Barotseland 1878-1969. A political history of Zambia's Western Province. London: C. Hurst \& Co.

Chungu, W. (2019). Constitutional making in Zambia: 1890-2015. Academia, 1-13. Retrieved on 8 November 2019, from https://www.academia.edu/26059873/Constitutional making in Zambia 1890-2015.

IDEA (2019). In Zambia, stakeholders submit views on proposed constitutional amendments to Parliament. ConstitutionNet, 9 September 2019. Retrieved on 8 November 2019, from http://constitutionnet.org/news/zambia-stakeholders-submit-views-proposedconstitutional-amendments-parliament.

Kaunda, Ch. J. (2018). Christianising Edgar Chagwa Lungu: The Christian nation, social media presidential photography and 2016 election campaign. Stellenboch Theological Journal, 4(1). Retrieved on 8 November 2019, from http://www.scielo.org.za/scielo.php?script=sci arttext\&pid=S2413$94672018000100013 \& \operatorname{lng}=$ en\&nrm=iso.

Lumina, C. (2019). Zambia's proposed constitutional amendments: Sowing the seeds of crisis? ConstitutionNet. Retrieved on 8 November 2019, from http://constitutionnet.org/news/zambias-proposed-constitutional-amendments-sowingseeds-crisis.

Maniatis, A. (2019). African constitutionalism and Barotseland, Open Journal for Legal Studies, 2(2), 4152. https://doi.org/10.32591/coas.0jls.0202.02041m

Maniatis, A. (2017). Droits sociaux et travail. Revue de la Recherche Juridique Droit Prospectif, XLII 168(3), 975-984.

Marinho, V. (2014). The tension between normativity and plurality in religious dogmas and in constitutional principles (pp. 1-25). Retrieved on 8 November 2019, from https://ssrn.com/abstract=2467160.

Metou, B. M. (2019). Existe-t-il une hiérarchie entre les normes constitutionnels des Etats africains? Afrilex, 1-32. Retrieved on 8 November 2019, from http://afrilex.ubordeaux4.fr/sites/afrilex/IMG/pdf/Existe-til_une_hierarchie_entre_les_normes_constitutionnelles_Metou.pdf.

Mwaebeme, É. St. (2019). Regard récent sur les tendances du constitutionnalisme africain. Le cas des États d'Afrique noire francophone, R.I.D.C., 1, 163-196.

Ndulo, M., \& Kent, R. (1996). Constitutionalism in Zambia: Past, present and future, JAL, 4O, 256-278.

Papagrigoriou, V. (1995). Comparative constitutional law. The path to "classical" republic: The case of Italy. Thessaloniki: Sakkoulas Editions (in Greek).

Sakala, J. B. (2013). The role of the judiciary in the enforcement of human rights in Zambia. Lusaka, Zambia: Image Publishers Limited.

Senou, J. L. (2019). Les figures de la séparation des pouvoirs en Afrique. RDP, 1, 183-216. 
A. Maniatis - Zambian Constitutional Normativity on Religion

Von Soest, Ch. (2009). The African state and its revenues. How politics influences tax collection in Zambia and Botswana. Nomos. 